\title{
15. ORGANIC GEOCHEMICAL CHARACTER OF SOME DEEP SEA DRILLING PROJECT CORES FROM LEGS 76 AND $44^{1}$
}

\author{
Barry Jay Katz, Texaco Inc., Bellaire Research Laboratories, Bellaire, Texas
}

\begin{abstract}
Pyrolysis assay, bitumen analysis, and elemental analysis of kerogen were used to characterize the organic matter of selected core samples from Hole 534A (Leg 76) and Hole 391C (Leg 44) on the Blake-Bahama Plateau. The organic matter throughout the stratigraphic section appears to be principally of a terrestrial origin. The data from several isolated horizons in the Hatteras and Blake-Bahama Formations imply the presence of significant quantities of autochthonous marine organic matter. However, these horizons appear so limited that they cannot be considered potential liquid hydrocarbon source rocks. All the analyzed samples are immature and have not evolved sufficiently to enter into the main stage of hydrocarbon generation.

The temporal and spatial restrictions of strata rich in marine organic matter suggest that they do not represent major expansions and contractions of anoxic bottom-water masses, but represent limited occurrences of anoxic conditions.
\end{abstract}

\section{INTRODUCTION}

The type, quantity, and distribution of organic matter in sediments offer insight into paleoceanographic conditions and hydrocarbon potential of a region. This chapter is aimed at determining the level of organic enrichment and the character of organic matter present within the stratigraphic columns of two closely spaced DSDP sites, Sites 391 and 534 (Fig. 1). It is hoped that this information can suggest a mechanism that will explain the variations in the carbonaceous sediments of the North Atlantic noted earlier by Tissot et al. (1980).

Organic matter can be characterized through several different procedures. This chapter relies principally on pyrolysis assay and the analysis of both soluble (bitumen) and insoluble (kerogen) organic components. Three types of organic matter are identified in this study: two are primary and the third is secondary or recycled.

One of the primary types has a marine origin. This material is derived from marine plankton. It is characterized by high atomic $\mathrm{H} / \mathrm{C}$ ratios, moderate atomic $\mathrm{O} / \mathrm{C}$ ratios, and high yields of total extractables and pyrolytic hydrocarbons relative to organic carbon content. This marine material has good potential for the generation of oil upon thermal maturation. It would be termed type II organic matter in the scheme of Tissot et al. (1974).

The second primary type is derived from higher continental plant detritus. This material is characterized by low to moderate atomic $\mathrm{H} / \mathrm{C}$ ratios, moderate to high atomic $\mathrm{O} / \mathrm{C}$ ratios, and low yields of total extractables and pyrolytic hydrocarbons relative to organic carbon content. It will normally generate gas upon thermal maturation and would be classified as type III organic matter (Tissot et al., 1974).

The third type of organic matter is derived from previously sedimented deposits and/or has undergone either

\footnotetext{
${ }^{1}$ Sheridan, R. E., Gradstein, F. M., et al., Init. Repts. DSDP, 76: Washington (U.S. Govt. Printing Office).
}

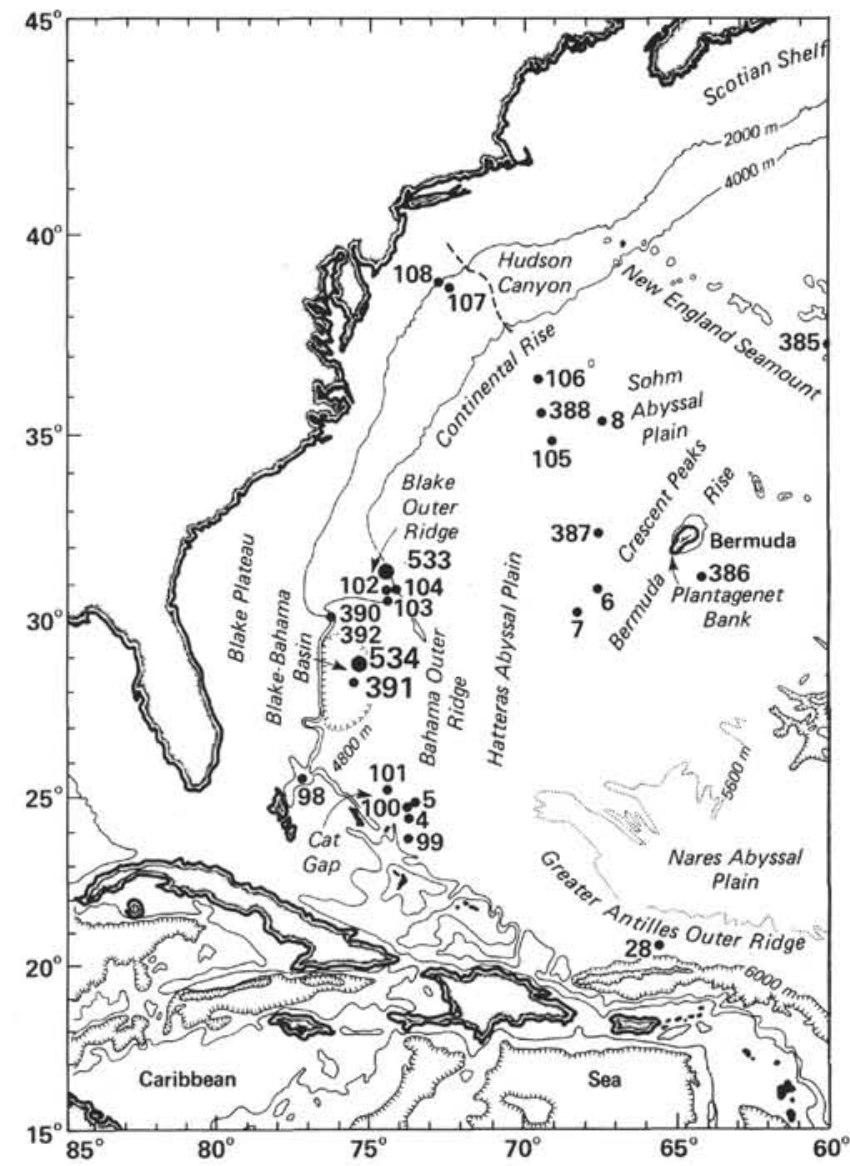

Figure 1. Location map for DSDP Sites 391 and 534.

severe thermal stress or oxidation. The material has very low atomic $\mathrm{H} / \mathrm{C}$ ratios and characteristically highly variable $\mathrm{O} / \mathrm{C}$ ratios. This material has very low yields of total extractables and pyrolytic hydrocarbons relative to organic carbon content. It is no longer capable of generating either gaseous or liquid hydrocarbons. This type 
of organic matter is commonly termed either R.O.M. (recycled organic matter) or type IV (Tissot et al., 1980).

\section{ANALYTICAL METHODOLOGY}

Fifty-three samples of approximately $50 \mathrm{~g}$ each were analyzed. Stratigraphic positions of the samples are summarized in Figures 2 and 3. Each sample was oven-dried at $60^{\circ} \mathrm{C}$ and ground to approximately 44 microns. Organic carbon content was determined using a LECO combustion system after decarbonating. Those samples with $\geq 0.5 \mathrm{wt} . \%$ organic carbon were analyzed further by pyrolysis in a Rock-Eval unit as described by Espitalié et al. (1977). Kerogen isolation and subsequent elemental analysis $(\mathrm{C}, \mathrm{H}, \mathrm{O}$, and $\mathrm{N})$ were performed on samples containing $\geq 1.0$ wt. \% organic carbon. A portion of each sample was extracted using an azeotropic mixture of chloroform, acetone, and methanol, followed by the precipitating of asphaltenes with pentane and separation by liquid chromatography.

\section{ANALYTICAL RESULTS}

\section{Organic Carbon}

At both sites, total organic carbon (TOC) contents are highly variable, ranging from less than $0.1 \mathrm{wt} . \%$ to greater than $4.6 \mathrm{wt} . \%$ (Table 1 ). The vertical variability of organic richness is presented in Figures 2 and 3. The two richest sections (534A-48-5 and 534A-53-2), with organic carbon contents of greater than $4.0 \mathrm{wt} . \%$, are Barremian/Hauterivian. Other samples with organic carbon values in excess of $1.0 \mathrm{wt} . \%$ are common to the $\mathrm{Al}$ bian and Aptian of both holes and are present within the Valanginian, Berriasian, and Kimmeridgian strata of Hole 534A. In general, samples with less than $0.3 \mathrm{wt} . \%$ TOC, the mean for DSDP material (McIver, 1975), are restricted to the pre- and post-Cretaceous samples of Hole 534A.

\section{Pyrolysis Assay (Rock-Eval)}

The total hydrocarbon yields, $\mathrm{S}_{1}$ (free, distillable hydrocarbons) $+\mathrm{S}_{2}$ (generatable hydrocarbons), range from less than $1 \mathrm{mg}$ hydrocarbons/g rock to greater than $18 \mathrm{mg}$ hydrocarbons/g rock (Table 1; Figs. 2 and $3)$. Potential or effective hydrocarbon source rocks display hydrocarbon yields of greater than $6 \mathrm{mg}$ hydrocarbons/g rock (Tissot and Welte, 1978). In the present study, source rocks of this quality are limited to Sections 534A-48-5 and 534A-53-2, which have yields of 14.32 and $18.19 \mathrm{mg}$ hydrocarbons/g rock, respectively.

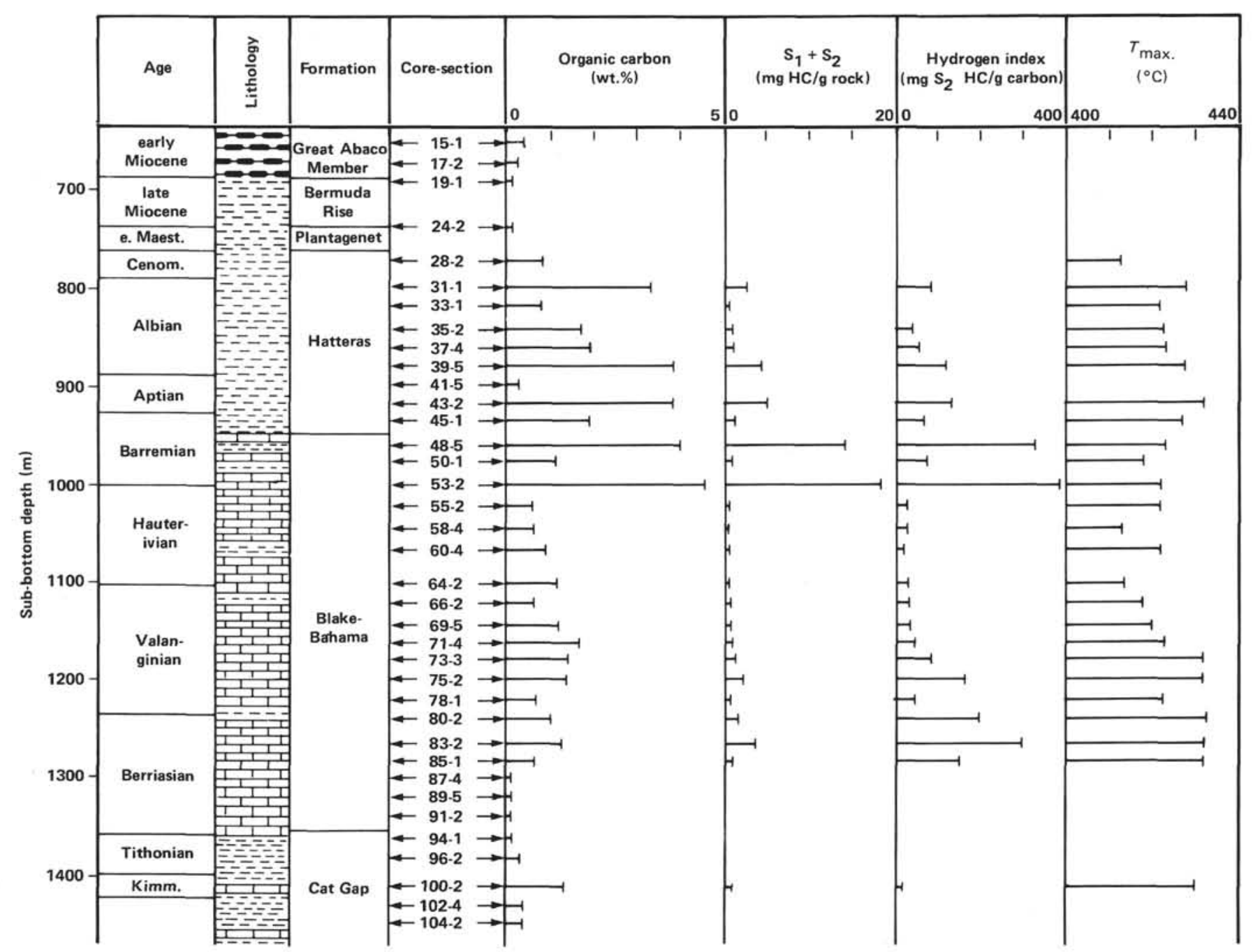

Figure 2. Stratigraphic summary of organic carbon and pyrolysis data from Hole 534A. 


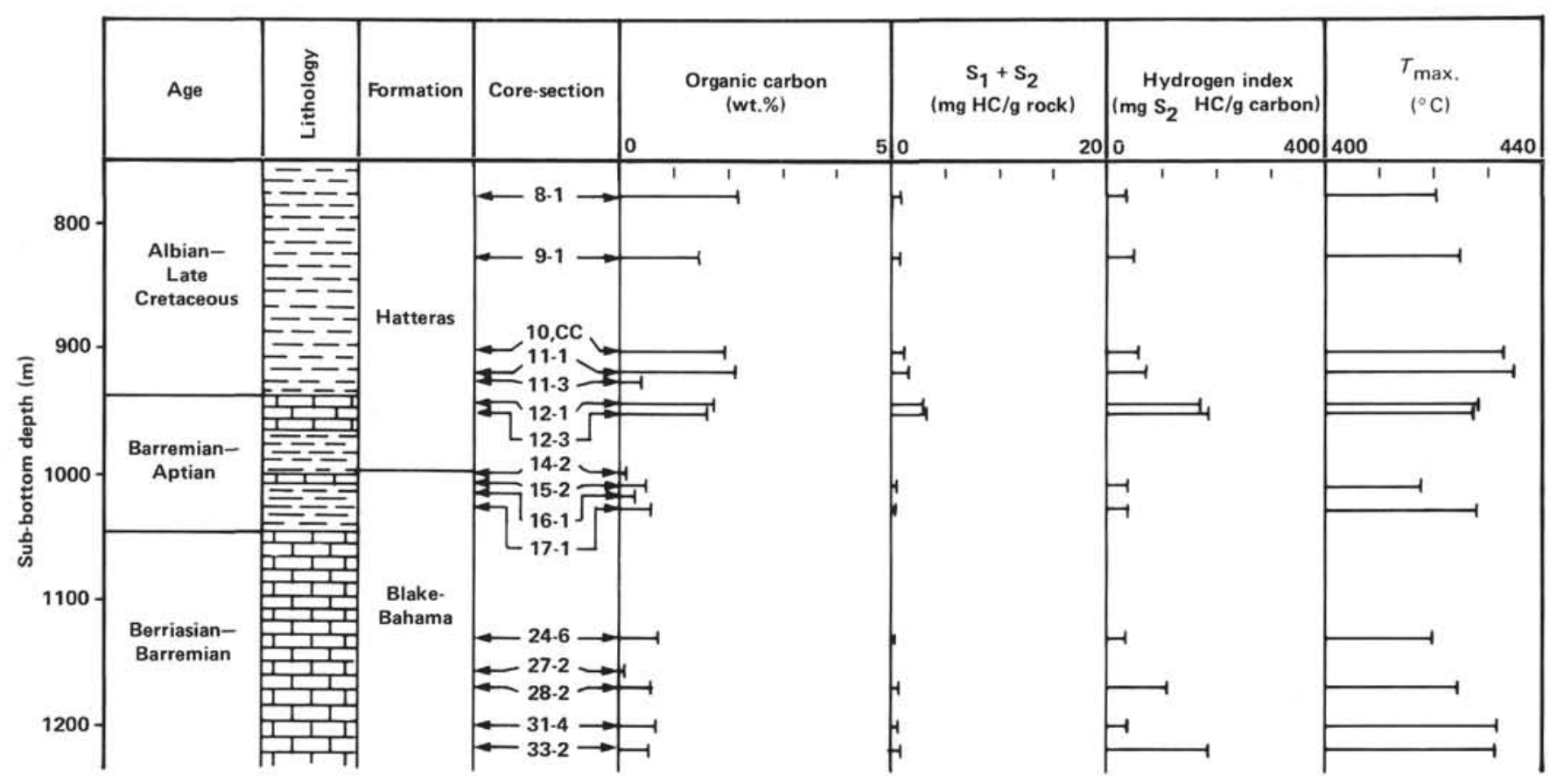

Figure 3. Stratigraphic summary of organic carbon and pyrolysis data from Hole 391C.

In addition to the screening of potential source facies, it has been suggested that the hydrogen index $\left(\mathrm{S}_{2} /\right.$ TOC) and oxygen index $\left(\mathrm{S}_{3}\right.$ or organic $\left.\mathrm{CO}_{2} / \mathrm{TOC}\right)$ are comparable to the $\mathrm{H} / \mathrm{C}$ and $\mathrm{O} / \mathrm{C}$ ratios, respectively (Espitalié et al., 1977). These indices (Fig. 4) suggest that the organic matter contained within the examined samples is principally of a terrestrial origin, largely vitrinitic or recycled, with a small mixed population plotting between type II (marine) and type III (vitrinitic) kerogens. This interpretation is tentative and must be confirmed by elemental analysis. The characterization of organic matter using pyrolysis data alone is subject to error because of the effects of both mineral matrix and level of organic enrichment (Katz, 1981).

Pyrolysis also offers an indication of organic maturity through both $T_{\max }$, the temperature at which there is maximum hydrocarbon generation, and the transformation ratio $\left(\mathrm{S}_{1} / \mathrm{S}_{1}+\mathrm{S}_{2}\right)$. All $T_{\max }$. values from the two sites are $435^{\circ} \mathrm{C}$ or less (Table 1; Figs. 2 and 3), indicating that the organic matter is thermally immature and has not entered into the stage of peak hydrocarbon generation. The transformation ratios obtained on those samples with sufficient hydrocarbon yields for the ratio to be meaningful are below 0.1 (Table 1), confirming the thermal immaturity of the organic matter.

\section{BITUMEN CHARACTERIZATION}

Bitumen yields ranged from as low as $59 \mathrm{ppm}$, essentially background, to as high as $2838 \mathrm{ppm}$ total extract (TOE, Table 2). Extract fractionation identified the material to be largely resins (NSOs) and asphaltenes with low hydrocarbon contents. The relative lack of hydrocarbons appears to reflect the immaturity of the sediment and the largely continental character of its organic matter.
Some samples have total extract yields inconsistent with both the low level of thermal maturity and the total organic carbon content. These anomalies are represented by extract to organic carbon ratios greater than 0.2 (TOE/TOC; Table 2). These elevated bitumen values may be due to either contamination or migration of mature "petroleumlike" material and subsequent alteration due to bacterial attack and/or gas deasphalting. The low level of hydrocarbons contained within these extracts favors the latter interpretation.

The elevated extractable yields do not appear to indicate favorable hydrocarbon generation potential within the section. Although according to some interpretational schemes (GeoChem Laboratories, Inc., 1980), total extractable yields in excess of $1000 \mathrm{ppm}$ indicate very good source potential, most such samples analyzed in the present study have pyrolytic hydrocarbon yields consistent with either poor or fair source rocks (Tissot and Welte, 1978). These low pyrolysis yields confirm that the bitumens are hydrogen depleted and are incapable of yielding hydrocarbons upon thermal cracking.

\section{ELEMENTAL ANALYSIS OF KEROGEN}

The elemental data, summarized in Table 3 and Figure 5 , confirm that the organic matter is largely derived from higher plants of terrestrial origin. The $\mathrm{H} / \mathrm{C}$ and $\mathrm{O} / \mathrm{C}$ ratios, plotted on a conventional van Krevelentype diagram, indicate that most of the analyzed material is rather closely aligned with the type III reference curve. A very small population, having $\mathrm{H} / \mathrm{C}$ and $\mathrm{O} / \mathrm{C}$ ratios that plot below the type III reference curve, was derived either from recycled material or from primary organic matter that had been strongly oxidized prior to its incorporation into the sedimentary column. 
Table 1. Organic carbon and pyrolysis assay. ${ }^{a}$

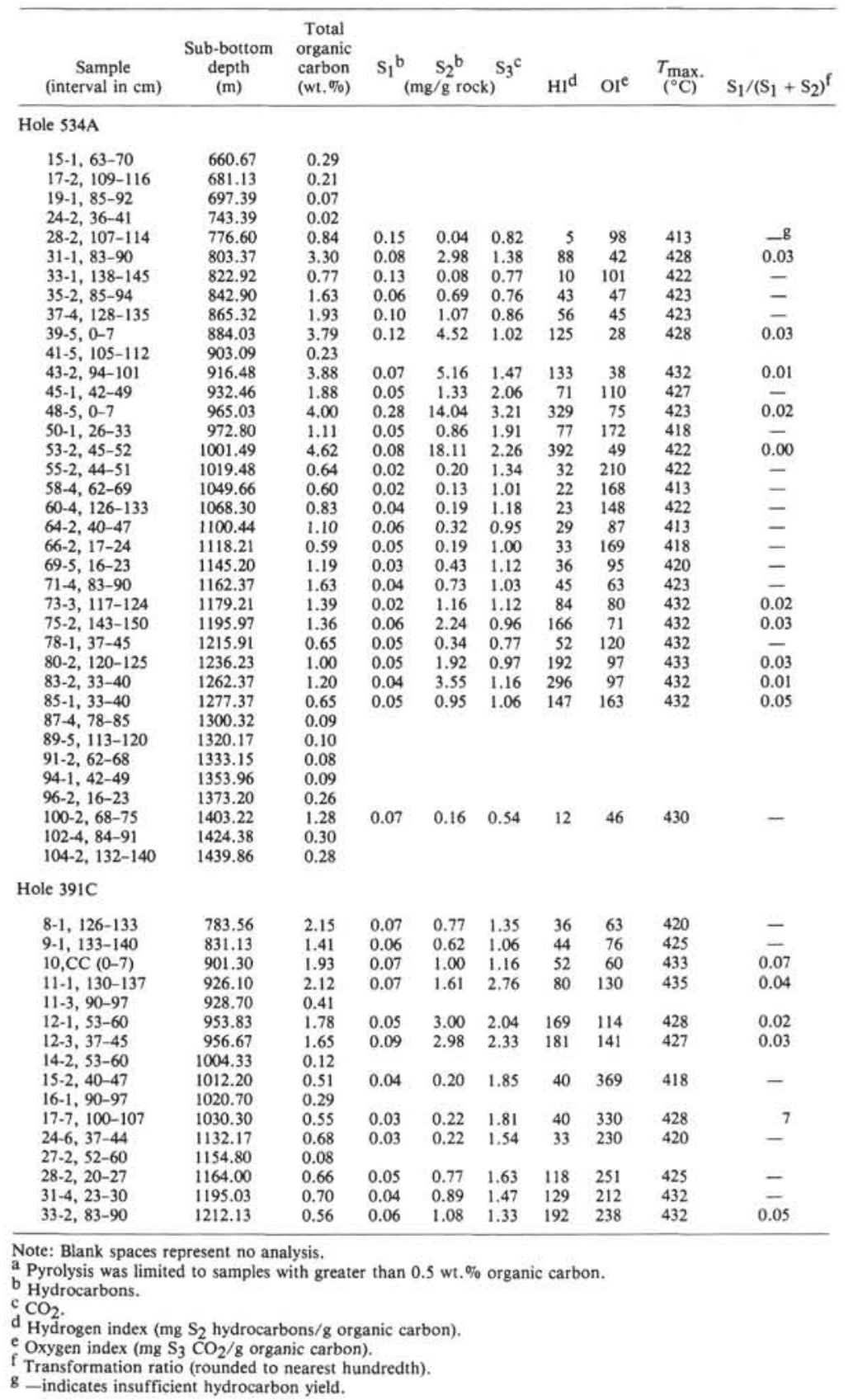

The data for a third population plot between reference curves II and III. The organic matter in these samples is a mixture of terrestrial- and marine-derived material. The relative amount of marine material varies from Section 534A-53-2, which plots very close to the type II reference curve, to Section 534A-48-5, which plots midway between the type II and type III reference ence curves. These discrete strata enriched in marine organic matter are Barremian/Hauterivian and Valanginian/Berriasian at Site 534 and Aptian at Site 391.

\section{DISCUSSION}

The preservation in the sedimentary column of primarily terrestrially derived organic matter does not re- quire strongly anoxic conditions (Demaison and Moore, 1980). Terrestrial material is partially oxidized and degraded during transport so that only the more stable components reach the final depocenter. As a result, terrestrial material may be preserved under oxic conditions. Therefore, although most of the Cretaceous and some of the Jurassic sediments examined contain aboveaverage quantities of organic carbon, they need not have been deposited under anoxic conditions. Their organic richness may reflect high continental organic productivities reflecting the warm and humid climatic conditions of the Cretaceous and Jurassic (Barron, 1980). Such conditions could have provided the large quantities of terrestrial material observed in the sediments 


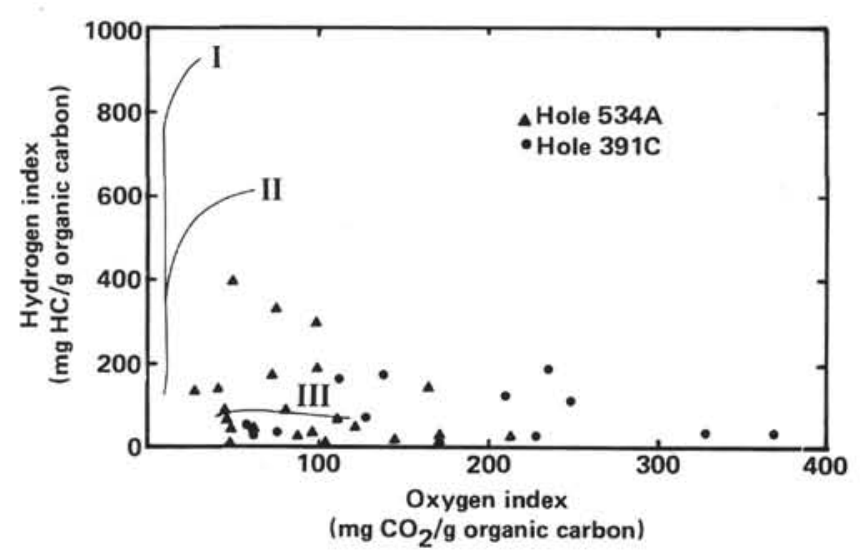

Figure 4. Modified van Krevelen diagram providing preliminary characterization of organic matter utilizing "Rock-Eval" pyrolysis. without regard to the oxidative state of the depositional environment. An oxic depositional environment is also consistent with the general paleocirculation patterns described by Sclater et al. (1977). For the Cretaceous and Jurassic, Sclater et al. (1977) suggest that deep water entered the North Atlantic through a gap between the Bahama Platform and the Guinea Nose. This would have resulted in oxygen renewal and maintenance of an oxic depositional environment.

Preservation of marine-derived organic matter, however, requires an anoxic environment. Such a condition implies isolation of a water mass, and a supply of consumable organic matter in excess of the available oxygen. Because of the poorly developed stratigraphic and spatial distribution of those strata found by this study to be enriched in type II kerogen, it is unlikely that they reflect the development of long-lived large anoxic water

Table 2. Bitumen characterization.

\begin{tabular}{|c|c|c|c|c|c|c|c|}
\hline $\begin{array}{c}\text { Sample } \\
\text { (interval in } \mathrm{cm} \text { ) }\end{array}$ & $\begin{array}{l}\text { Sub-bottom } \\
\text { depth } \\
\text { (m) }\end{array}$ & $\begin{array}{l}\text { Total } \\
\text { extract } \\
\text { (ppm) }\end{array}$ & $\begin{array}{c}\text { Asphaltenes } \\
(\%)\end{array}$ & $\begin{array}{c}\text { Saturates } \\
(\%)\end{array}$ & $\begin{array}{c}\text { Aromatics } \\
(\%)\end{array}$ & $\begin{array}{l}\text { NSOs } \\
(\%)\end{array}$ & TOE/TOC ${ }^{b}$ \\
\hline \multicolumn{8}{|l|}{ Hole 534A } \\
\hline $15-1,63-70$ & 660.67 & 138 & 20.0 & 7.5 & 12.5 & 60.0 & 0.05 \\
\hline $17-2,109-116$ & 681.13 & 106 & 16.1 & 24.9 & 24.9 & 34.2 & 0.05 \\
\hline $19-1,85-92$ & 697.39 & 97 & 0.0 & 45.2 & 41.9 & 12.9 & 0.14 \\
\hline $24-2,36-41$ & 743.39 & 155 & 45.5 & 13.6 & 22.7 & 18.2 & 0.78 \\
\hline $28-2,107-114$ & 776.60 & 312 & 45.6 & 15.2 & 13.1 & 26.1 & 0.04 \\
\hline $31-1,83-90$ & 803.37 & 735 & 41.7 & 6.4 & 6.0 & 45.9 & 0.02 \\
\hline $33-1,138-145$ & 822.92 & 211 & 54.2 & 11.1 & 12.6 & 22.1 & 0.03 \\
\hline $35-2,85-94$ & 842.90 & 281 & 18.8 & 8.8 & 11.3 & 61.3 & 0.02 \\
\hline $37-4,128-135$ & 865.32 & 436 & 37.5 & 9.4 & 8.6 & 48.5 & 0.02 \\
\hline $39-5,0-7$ & 884.03 & 685 & 37.6 & 6.9 & 5.9 & 59.5 & 0.02 \\
\hline $41-5,105-112$ & 903.09 & 59 & 0.0 & 34.8 & 32.6 & 32.6 & 0.03 \\
\hline $43-2,94-101$ & 916.48 & 811 & 33.7 & 9.1 & 11.1 & 46.0 & 0.02 \\
\hline $45-1,42-49$ & 932.46 & 1016 & 63.9 & 8.0 & 4.0 & 24.2 & 0.05 \\
\hline $48-5,0-7$ & 965.03 & 2090 & 51.2 & 4.3 & 11.2 & 33.2 & 0.05 \\
\hline $50-1,26-33$ & 972.80 & 1143 & 71.3 & 5.3 & 8.8 & 14.6 & 0.10 \\
\hline $53-2,45-52$ & 1001.49 & 1971 & 53.7 & 5.2 & 11.6 & 28.6 & 0.04 \\
\hline $55-2,44-51$ & 1019.48 & 1985 & 90.2 & 2.3 & 3.1 & 4.3 & 0.30 \\
\hline $58-4,62-69$ & 1049.66 & 831 & 81.3 & 5.4 & 5.4 & 7.8 & 0.14 \\
\hline $60-4,126-133$ & 1068.30 & 2344 & 90.6 & 2.0 & 1.2 & 6.2 & 0.28 \\
\hline $64-2,40-47$ & 1100.44 & 1073 & 79.3 & 6.6 & 6.9 & 7.2 & 0.10 \\
\hline $66-2,17-24$ & 1118.21 & 1652 & 89.2 & 2.0 & 5.0 & 3.8 & 0.28 \\
\hline $69-5,16-23$ & 1145.20 & 1795 & 87.0 & 1.6 & 3.9 & 7.6 & 0.15 \\
\hline $71-4,83-90$ & 1162.37 & 1150 & 77.8 & 6.1 & 7.8 & 8.4 & 0.07 \\
\hline $73-3,117-124$ & 1179.21 & 1224 & 75.3 & 6.0 & 8.5 & 10.1 & 0.09 \\
\hline $75-2,143-150$ & 1195.97 & 2838 & 86.4 & 3.7 & 2.8 & 7.2 & 0.21 \\
\hline $78-1,37-45$ & 1215.91 & 2119 & 87.4 & 4.1 & 4.2 & 4.4 & 0.33 \\
\hline $80-2,120-125$ & 1236.23 & 609 & 62.4 & 7.2 & 9.9 & 20.5 & 0.06 \\
\hline $83-2,33-40$ & 1262.37 & 1345 & 68.2 & 4.5 & 5.5 & 21.8 & 0.11 \\
\hline $85-1,33-40$ & 1277.37 & 854 & 73.1 & 7.4 & 6.6 & 12.9 & 0.13 \\
\hline $87-4,78-85$ & 1300.32 & 484 & 75.8 & 5.4 & 6.7 & 12.0 & 0.54 \\
\hline $89-5,113-120$ & 1320.17 & 821 & 82.8 & 5.7 & 4.9 & 6.6 & 0.82 \\
\hline $91-2,62-68$ & 1333.15 & 399 & 62.8 & 11.6 & 13.2 & 12.4 & 0.50 \\
\hline $96-2,16-23$ & 1373.20 & 457 & 59.9 & 13.4 & 11.3 & 15.5 & 0.18 \\
\hline $100-2,68-75$ & 1403.22 & 1591 & 90.2 & 1.8 & 2.2 & 5.9 & 0.12 \\
\hline $102-4,84-91$ & 1424.38 & 1833 & 91.4 & 1.6 & 2.2 & 4.7 & 0.61 \\
\hline $104-2,132-140$ & 1439.86 & 120 & 23.7 & 16.2 & 25.4 & 34.7 & 0.04 \\
\hline \multicolumn{8}{|l|}{ Hole $391 \mathrm{C}$} \\
\hline $8-1,126-133$ & 783.56 & 1371 & 55.1 & 25.8 & 6.3 & 12.8 & 0.06 \\
\hline $9-1,133-140$ & 831.13 & 522 & 37.1 & 9.9 & 11.7 & 41.3 & 0.04 \\
\hline $10, \mathrm{CC}(0-7)$ & 901.30 & 549 & 37.5 & 9.4 & 24.4 & 28.8 & 0.03 \\
\hline $11-1,130-137$ & 926.10 & 658 & 34.2 & 9.2 & 8.7 & 48.0 & 0.03 \\
\hline $11-3,90-97$ & 928.70 & 238 & 8.5 & 17.8 & 24.6 & 49.2 & 0.06 \\
\hline $12-1,53-60$ & 953.83 & 966 & 46.0 & 6.7 & 20.3 & 27.0 & 0.06 \\
\hline $12-3,37-45$ & 956.67 & 873 & 45.2 & 9.6 & 9.6 & 34.5 & 0.05 \\
\hline $14-2,53-60$ & 1004.33 & 124 & 0.0 & 30.6 & 27.8 & 41.7 & 0.10 \\
\hline $15-2,40-47$ & 1012.20 & 232 & 16.9 & 17.2 & 27.2 & 38.7 & 0.05 \\
\hline $16-1,90-97$ & 1020.70 & 124 & 11.1 & 25.0 & 22.2 & 41.7 & 0.04 \\
\hline $17-1,100-107$ & 1030.30 & 229 & 38.8 & 14.9 & 14.9 & 31.3 & 0.04 \\
\hline $24-6,37-44$ & 1132.17 & 263 & 35.1 & 13.0 & 14.3 & 37.7 & 0.04 \\
\hline $27-2,52-60$ & 1154.80 & 112 & 3.0 & 24.2 & 24.2 & 48.5 & 0.14 \\
\hline $28-2,20-27$ & 1164.00 & 373 & 35.1 & 16.8 & 29.2 & 18.9 & 0.06 \\
\hline $31-4,23-30$ & 1195.03 & 388 & 35.0 & 18.0 & 12.8 & 34.2 & 0.06 \\
\hline $33-2,83-90$ & 1212.13 & 285 & 31.8 & 13.9 & 21.2 & 34.1 & 0.05 \\
\hline
\end{tabular}

a Paraffins and napthenes.

b Total organic extract/total organic carbon. 
Table 3. Elemental composition (ash-free basis).

\begin{tabular}{|c|c|c|c|c|c|c|c|}
\hline \multirow{2}{*}{$\begin{array}{c}\text { Sample } \\
\text { (interval in } \mathrm{cm} \text { ) }\end{array}$} & \multirow{2}{*}{$\begin{array}{l}\text { Sub-bottom } \\
\text { depth } \\
\text { (m) }\end{array}$} & \multirow{2}{*}{$\mathrm{H}$} & \multirow{2}{*}{\multicolumn{2}{|c|}{$\begin{array}{l}\text { C } \\
\text { (wt.\%) }\end{array}$}} & \multirow{2}{*}{$\mathrm{N}$} & \multicolumn{2}{|c|}{$\begin{array}{l}\text { Atomic } \\
\text { ratios }\end{array}$} \\
\hline & & & & & & $\mathrm{H} / \mathrm{C}$ & $\mathrm{O} / \mathrm{C}$ \\
\hline \multicolumn{8}{|l|}{ Hole 534A } \\
\hline $31-1,83-90$ & 803.87 & 5.7 & 69.5 & 15.3 & 2.8 & 0.99 & 0.165 \\
\hline $35-2,85-94$ & 842.90 & 5.4 & 73.4 & 14.6 & 2.4 & 0.89 & 0.149 \\
\hline $37-4,128-135$ & 865.32 & 5.7 & 73.5 & 14.8 & 2.6 & 0.93 & 0.151 \\
\hline $39-5,0-7$ & 884.84 & 5.5 & 72.3 & 14.7 & 2.4 & 0.92 & 0.153 \\
\hline $43-2,94-101$ & 916.48 & 5.7 & 73.1 & 14.7 & 2.8 & 0.94 & 0.151 \\
\hline $45-1,42-49$ & 932.46 & 5.3 & 72.4 & 14.7 & 2.5 & 0.87 & 0.152 \\
\hline $48-5,0-7$ & 965.03 & 6.5 & 71.8 & 11.8 & 2.8 & 1.08 & 0.123 \\
\hline $53-2,45-52$ & 1001.49 & 7.2 & 69.0 & 11.5 & 2.1 & 1.25 & 0.125 \\
\hline $64-2,40-47$ & 1100.44 & 4.5 & 72.9 & 16.5 & 1.9 & 0.73 & 0.170 \\
\hline $69-5,16-23$ & 1145.20 & 4.0 & 65.0 & 13.4 & 1.6 & 0.73 & 0.155 \\
\hline $71-4,83-90$ & 1163.37 & 4.9 & 67.3 & 14.4 & 2.1 & 0.87 & 0.161 \\
\hline $73-3,117-124$ & 1179.21 & 5.8 & 73.6 & 13.4 & 2.4 & 0.95 & 0.136 \\
\hline $75-2,143-150$ & 1195.97 & 6.9 & 71.8 & 12.4 & 2.6 & 1.16 & 0.130 \\
\hline $80-2,120-125$ & 1236.23 & 7.0 & 72.0 & 13.4 & 2.4 & 1.17 & 0.139 \\
\hline $83-2,33-40$ & 1262.37 & 7.4 & 73.1 & 12.7 & 2.5 & 1.22 & 0.130 \\
\hline \multicolumn{8}{|l|}{ Hole 391C } \\
\hline $9-1,133-140$ & 831.13 & 4.6 & 71.2 & 15.1 & 2.1 & 0.78 & 0.159 \\
\hline $10, \mathrm{CC}(0-7)$ & 901.30 & 5.2 & 71.7 & 14.4 & 2.2 & 0.87 & 0.150 \\
\hline $11-1,130-137$ & 926.10 & 5.4 & 70.5 & 14.5 & 2.5 & 0.92 & 0.154 \\
\hline $12-1,53-60$ & 953.83 & 6.7 & 68.7 & 12.8 & 2.6 & 1.17 & 0.140 \\
\hline $12-3,37-45$ & 956.67 & 5.8 & 72.1 & 12.1 & 2.0 & 0.96 & 0.126 \\
\hline $31-4,23-30$ & 1195.08 & 5.2 & 70.4 & 15.2 & 2.3 & 0.88 & 0.162 \\
\hline
\end{tabular}

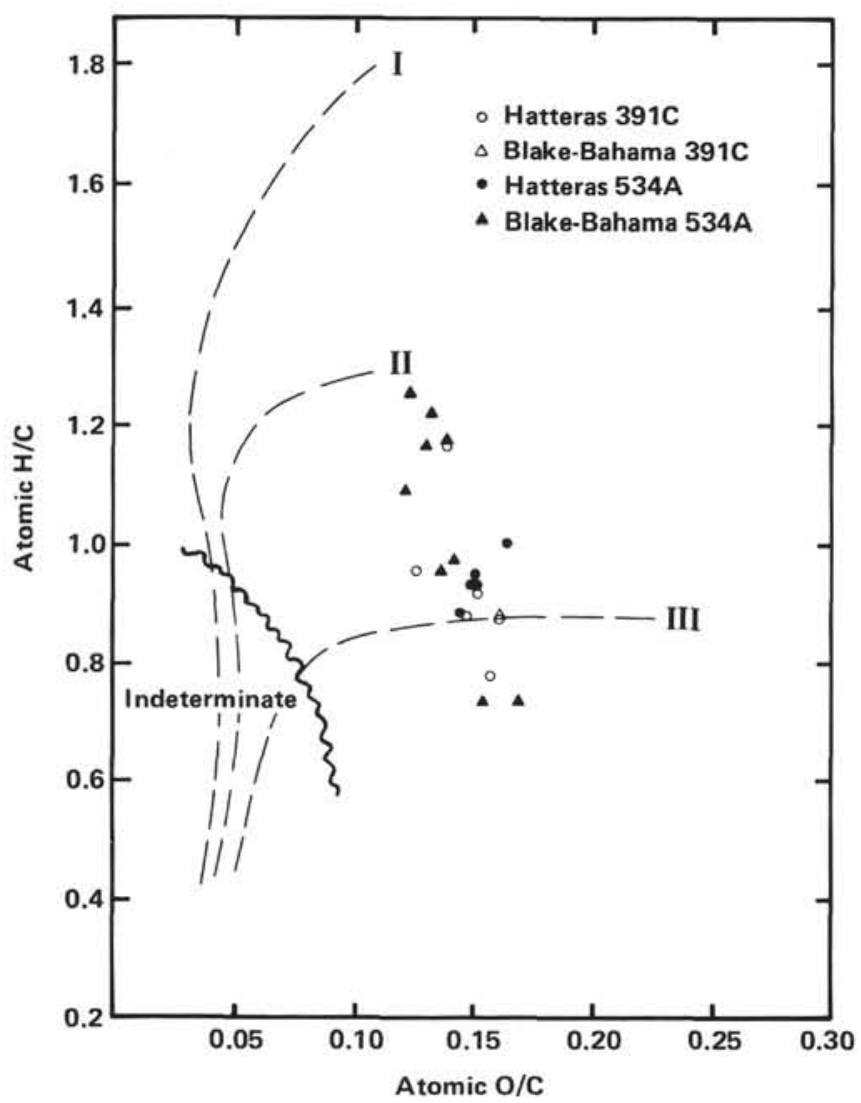

Figure 5. Van Krevelen diagram providing final characterization of organic matter.

masses. It is possible that they represent brief periods of stagnation and high productivity, which may or may not be synchronous basin-wide. These stagnant conditions may have resulted from changes in general bottom-water circulation, whereby oxygenated bottom water was briefly cut off from the Pacific by tectonic activity of the "Panama barrier" (Saunders et al., 1973) or by transient changes in deep-water eddy patterns capable of isolating bottom-water pockets.

As a consequence of the limited stratigraphic distribution of these marine organic facies, it does not appear probable that they represent potential oil source facies. These data also imply that broad generalizations and predictions of hydrocarbon source qualities based solely on limited well control data should be viewed cautiously.

\section{SUMMARY}

1. The preserved organic matter is principally continental in origin and therefore has only limited potential to generate liquid hydrocarbons.

2. Discrete Aptian, Barremian/Hauterivian, and Valanginian/Berriasian strata contain significant contributions of marine organic matter, suggesting anoxic depositional conditions.

3. Only strata within the Barremian/Hauterivian sections of Hole 534A have hydrocarbon yields indicative of good potential source facies.

4. The spatial and temporal distribution of marine horizons at these two sites on the western Atlantic continental margin suggests that they are not related to development of long-lived anoxic water masses, but rather may reflect brief changes in bottom-water circulation.

\section{ACKNOWLEDGMENTS}

The author wishes to thank Drs. J. M. N. Evans, J. E. Lacey, E. H. Man, and R. N. Pheifer for their critical comments. The author acknowledges the permission of Texaco Inc. to publish this chapterTexaco Contribution No. 2577.

\section{REFERENCES}

Barron, E. J., 1980. Paleogeography and climate, 180 million years to the present [Ph.D. dissert.]. University of Miami, Coral Gables, Florida.

Demaison, G. J., and Moore, G. T., 1980. Anoxic environments and oil source bed genesis. Am. Assoc. Pet. Geol. Bull., 64:1179-1209.

Espitalié, J., Madec, M., Tissot, B., Mennig, J. J., and Leplat, P., 1977. Source rock characterization method for petroleum exploration. Proc. 1977 Offshore Technol. Conf., 3:439-443.

GeoChem Laboratories, Inc., 1980. Source Rock Evaluation Reference Manual: Houston, Texas (GeoChem Laboratories, Inc.).

Katz, B. J., 1981. The limitations of Rock-Eval pyrolysis for typing organic matter. An. Assoc. Pet. Geol. Bull., 65:944. (Abstract)

McIver, R. D., 1975. Hydrocarbon occurrences from JOIDES Deep Sea Drilling Project. Proc. 9th World Petrol. Congr., 2:269-280.

Saunders, J. B., Edgar, N. T., Donnelly, T. W., and Hay, W. W., 1973. Cruise Synthesis. In Edgar, N. T., Saunders, J. B., et al., Init. Repts. DSDP, 15: Washington (U.S. Govt. Printing Office), 1077-1111.

Sclater, J. G., Hellinger, S., and Tapscott, C., 1977. The paleobathymetry of the Atlantic Ocean from the Jurassic to present. $J$. Geol., 85:509-552.

Tissot, B., Demaison, G., Masson, P., Delteil, J. R., and Combaz, A., 1980. Paleoenvironment and petroleum potential of Middle Cretaceous black shales in Atlantic Basins. Am. Assoc. Pet. Geol. Bull., 64:2051-2063.

Tissot, B., Durand, B., Espitalié, J., and Combaz, A., 1974. Influence of the nature and diagenesis of organic matter in formation of petroleum. Am. Assoc. Pet. Geol. Bull., 58:499-506.

Tissot, B. P., and.Welte, D. H., 1978. Petroleum Formation and Occurrence: New York (Springer-Verlag).

Date of Initial Receipt: April 12, 1982 